\title{
YERBILIMLERI
}

Bulletin for Earth Sciences

Yerbilimleri, 2020, 41 (1), 100-113, DOI:10.17824/yerbilimleri.664025

Hacettepe Üniversitesi Yerbilimleri Uygulama ve Araştırma Merkezi Bülteni

Bulletin of the Earth Sciences Application and Research Centre of Hacettepe University

\section{Bir Yeraltı Altın Madeninde Kişisel Koruyucu Donanımlar İçin Risk Değerlendirilmesi}

Risk Assessment for Personal Protective Equipment in an Underground Gold Mine

\author{
IBRAHIM ÇAVUŞOĞLU ${ }^{*, 1}$, HATUN EKTi ${ }^{2}$, ASLIHAN GÜVENDi ${ }^{2}$, AHMET GÖKCAN $^{2}$, HATICE DEMIR ${ }^{2}$ \\ ${ }^{1}$ Gümüşhane Üniversitesi, Maden Mühendisliği Bölümü, 29100, Gümüşhane, Türkiye \\ ${ }^{2}$ Gümüşhane Üniversitesi, Iş Sağı̆̆ı ve Güvenliği Bölümü, 29100, Gümüşhane, Türkiye
}

Geliş (received): 23 Aralık (December) 2019

Kabul (accepted) : 27 Nisan (April) 2020

\section{Öz}

İş sağlığı ve güvenliği bakımından güvenli çalışma ortamlarının oluşturulması için öncesinde yapılan risk değerlendirilmesi ile olası tehlikeler belirlenerek onlara karşı koruyucu ve önleyici tedbirler alınarak toplu koruma sağlanmaktadır. Ancak toplu korumanın sağlanamadığı durumlarda Kişisel Koruyucu Donanımların (KKD) kullanımları ortaya çıkmaktadır. Bu çalışmada ilk olarak bir yeraltı altın madeninde çalışanların kullandıkları KKD'lar belirlenmiş ve sonrasında çalışanların KKD kullanmadığı durumlara yönelik Risk değerlendirme matrisi (L-Tipi) metodu kullanılarak risk analizi yapılmıştır. KKD kullanılmadığında ortaya çıkabilecek olan tehlike ve riskler yeraltı koşullarında yerinde inceleme yapılarak belirlenmiştir. Çalışma sonucunda yeraltı altın madeninde kullanılan hemen hemen tüm KKD materyalleri için risk değerlendirmeleri Kabul Edilemez ve Dikkate Değer Risk olarak çıkmıştır. Bu çerçevede alınması gereken önlemler de çalışmada değerlendirilmiştir.

Anahtar Kelimeler: İş Sağlığı ve Güvenliği, Kişisel Koruyucu Donanımlar, L-Tipi Matris Yöntemi, Risk Değerlendirmesi, Yeraltı Altın Madeni.

https://doi.org/10.17824/yerbilimleri.664025

*Ibrahim ÇAVUŞOĞLU cavusogluibrahim@hotmail.com

${ }^{1}$ Gümüşhane Üniversitesi, Maden Mühendisliği Bölümü, 29100, Gümüşhane, Türkiye, ORCID 0000-0003-0145-7523

${ }^{2}$ Gümüșhane Üniversitesi, Iss Sağlığı ve Güvenliği Bölümü, 29100, Gümüșhane, Türkiye, ORCID 0000-0002-5044-8992

${ }^{2}$ Gümüşhane Üniversitesi, İ̧ Sağlığı ve Güvenliği Bölümü, 29100, Gümüşhane, Türkiye, ORCID 0000-0002-8331-232X

${ }^{2}$ Gümüşhane Üniversitesi, Iş Sağlığı ve Güvenliği Bölümü, 29100, Gümüşhane, Türkiye, ORCID 0000-0002-2257-4668

${ }^{2}$ Gümüşhane Üniversitesi, Iş Sağlığı ve Güvenliği Bölümü, 29100, Gümüşhane, Türkiye, ORCID 0000-0003-2585-4777 


\section{ABSTRACT}

To create safe working environments in terms of occupational health and safety, the possible risks are first determined by the risk analysis method and collective protection is provided by taking protective and preventive measures against these risks. However, when collective protection cannot be provided, the use of Personal Protective Equipment (PPE) occurs. In this study, first of all, the PPE used by the mine workers in an underground gold mine was determined and then the risk analysis was performed by using the Risk Assessment Matrix (L-Type) method for the cases where the employees did not use PPE. Hazards and risks that may arise when PPE is not used have been identified by making on-site investigations in underground conditions. As a result of the study, the risk assessments for almost all PPE materials used in underground gold mine were found to be Unacceptable and Notable Risk. Measures to be taken were also evaluated in the study.

Keywords: Occupational Health and Safety, Personal Protective Equipment, L-Type Matrix Method, Risk Assessment, Underground Gold Mine.

\section{GíRiş}

Madencilik insanoğlunun hayatında vazgeçilmez bir yer tutarak tarih boyunca toplumların gelişmelerine katkıda bulunan bir sektördür. Özellikle tarım ile birlikte tüm dünyada hammadde ihtiyacını karşılayan iki temel üretim alanından birisi konumundadır (Ernst \& Young, 2012). Ancak sektörde yoğun iş gücü olması iş kazalarının ve meslek hastalıklarının görülme sıklığını arttırmaktadır. Madencilik sektörü, iş kazaları ve meslek hastaları bakımından değerlendirildiğinde tüm dünyada tehlikeli ve riskli sektörler arasında kabul edilmektedir (Yaşar vd., 2015). Bundan dolayıdır ki çalışan sayısının yüksek ve emeğin yoğun olduğu bu sektörde iş sağlığı ve güvenliği tedbirlerine önem verilmesi gerektiği açıktır.

Tüm alanlarda iş sağlığı ve güvenliğinin asıl amacı; çalışma yaşamında çalışanların sağlığına zarar verebilecek hususları önceden belirleyerek gereken önlemleri almak, rahat ve güvenli bir ortamda çalışmalarını sağlamak, iş kazaları ve meslek hastalıklarına karşı çalışanların psikolojik ve bedensel sağlıklarını korumaktır (Cervatoğlu, 2003). Diğer bir ifadeyle, iş yerlerinde sağlıklı ve güvenli çalışma ortamlarının oluşturulması için riskleri önceden belirlemek ve bu risklere karşı koruyucu ve önleyici tedbirleri alarak toplu 
korumayı sağlamaktır. Ancak işyerindeki risklerin önlenmesinin veya yeteri derecede azaltılmasının, toplu koruma, iş organizasyonu veya çalışma yöntemleri ile sağlanamadığı durumlarda Kişisel Koruyucu Donanım (KKD) kullanım gereksinimi ortaya çıkmaktadır (Kahya vd., 2019). KKD’lar çalışanların sağlıklı ve güvenli olarak çalışmalarını sağlamak amacıyla, kaynağında kontrol altına alınamayan risklere, çalışma ortamında zarar verici etkenlere maruz kalmaya ve tehlikelerden olumsuz etkilenmeye karşı koruyucu olarak kullanılırlar.

İş kazaları ve meslek hastalıkları bakımından en riskli sektörler arasında yer alan madencilikte çalışanlar yeraltı ve yerüstü ocaklarda göçük, gaz ve toz patlamaları, yeraltı yangın ve su baskınları vb. gibi birçok riskli durumlarla karşı karşıya kalabilmektedir (Önder vd., 2011a). Bunların yanında toz kaynaklı Pnömokonyoz, Silikozis, Antrakozis gibi bazı bazı meslek hastalığı riskleri de madencilik sektöründe sıkça görülmektedir. Bu tip risk faktörlerini açığa çıkmadan kaynağında kontrol altına almak veya yok etmek için alınan tedbirlerin bazen yeterli olamayacağı durumlarda KKD kullanılması bireysel korunmada kaçınılmazdır (Tozman, 2010). Bu durumda özellikle madencilik gibi tehlikeli sektörlerde işverenin ve çalışanların ortak çabaları çalışanlar için mümkün olan en iyi korumanın sağlanması, sağlıklı bir çalışma ortamı oluşturulması ve bunun sürdürülebilmesi için önemlidir (OSHA, 2004; Akpınar, 2015; Karaahmetoğlu, 2019). Sağlıklı bir çalışma ortamının sağlanması için de işveren ve çalışanların KKD’lara yönelik bazı sorumluluklarını yerine getirmeleri elzem olmaktadır.

Genel olarak işveren sorumlulukları (OSHA, 2004):

- Fiziksel ve sağlık tehlikelerini tanımlamak ve kontrol etmek için işyerinde "risk değerlendirmesi" yapmak,

- Çalışanlar için uygun KKD belirlemek ve sağlamak,

- Çalışanları KKD kullanımı ve bakımı konusunda eğitmek,

- Aşınmış veya hasar görmüş KKD'ın değiştirilmesi de dahil olmak üzere KKD'ı korumak,

- KKD programının etkinliğini periyodik olarak gözden geçirmek, güncellemek ve değerlendirmek,

Genel olarak çalışan sorumlulukları (OSHA, 2004):

- Uygun KKD giymek,

- KKD ile ilgili eğitim oturumlarına katılmak,

- KKD'ye özen göstermek, temizlemek ve bakımını yapmak,

- KKD'yi tamir etme veya değiştirme intiyacı konusunda bir amiri bilgilendirmek. 
Risk değerlendirmesi tüm tehlike sınıfında yer alan (az tehlikeli, tehlikeli ve çok tehlikeli) işletmelerde yapılacak olan iş sağlığı ve güvenliği risk yönetimi adımlarının en başında gelmektedir (Resmi Gazete, 2012). Risk değerlendirmesi çalışma ortamında önleyici bir yaklaşım sergileyerek güvenli ve sağlıklı bir çalışma ortamı oluşturmak amacıyla yapılmaktadır. Risklerin belirlenmesi için literatürde bulunan risk metotlarından bir veya birkaçı kullanılabilir (Özkılıç, 2005). Genel olarak Nitel (kalitatif), Nicel (kantitatif) ve hem nicel hem de nitel (Karma) olmak üzere üç farklı biçimde metotlar mevcuttur. Her bir metot kendi içerisinde farklı analiz yöntemleri barındırmaktadır. Uygulamada en çok kullanılan yöntemlerinden birisi ise risk değerlendirme karar matris metodolojisidir. Bu metot uygulamada kullanımı açısından basit ve sade olması analistler için ideal durmaktadır. Ancak çok farklı ve karmaşık süreçlere sahip işletmeler için tek başına yeterli olmayabilir. Ayrıca risk değerlendirmesi yapan uzmanın bilgi birikimine göre de metodun başarısı değişkenlik gösterebilmektedir (Karvan, 2019).

Bugüne kadar madencilik sektörüne yönelik yapılan risk değerlendirme çalışmalarının genel olarak çalışma alanında oluşabilecek tehlike ve riskler veya uygun risk metodu seçimleri üzerine olduğunu görmekteyiz (Karadağ, 2000; Kasap ve Subaşı, 2011; Önder vd., 2011b; Çolak vd., 2018; Koçak, 2019; Hasanhanoğlu, 2020). Madencilik sektöründe KKD kullanımlarına yönelik yapılmış risk değerlendirme çalışmalarının hemen hemen olmadığını görmekteyiz. ÇSGB (2016) yaptığı çalışmasında madencilik sektöründe olası tehlike ve risklerden bahsetmiş ve sektörde çalışanların KKD kullanımına yönelik mevcut durum analizi yapmıştır. Eser (2015) çalışmasında ise maden işlerinde çalışma ortamında solunumun korunması gereken durumları ve ortamları incelenmiş ve madenlerde çalışma ortamında solunum koruyucular için uygun ekipmanlar ve ekipman seçimindeki parametreleri irdelemiştir.

$\mathrm{Bu}$ çalışmada, Gümüşhane ilinde yeraltı üretim yöntemiyle faaliyetlerine devam eden bir altın madeninde yeraltında çalışanların, kullanmaları gereken KKD’lar ve kullanım durumları belirlenecek sonrasında KKD'ları uygun kullanmadıkları veya hiç kullanmadıklarında oluşabilecek tehlikeler risk değerlendirme karar matris metoduyla analiz edilmiştir. 


\section{MATERYAL VE METOT}

\section{Materyal}

Bu çalışmada, Gümüşhane ilinde faaliyet gösteren ve yeraltı üretim yöntemiyle üretim gerçekleştiren bir altın madeninde yeraltı çalışanlarının kullandıkları KKD’lar ve yeraltı çalışma ortamı ve şartları incelemeye konu olmuştur.

\section{Metot}

Çalışmada ilk önce yeraltında kes-doldur üretim metoduyla faaliyet sürdüren bir altın madeninde yeraltında çalışanların kullanması gereken KKD’lar işletmelerde gözlem ve deneyimler sonrasında belirlenmiştir.

Belirlenen KKD'lar toplu korumdan çok bireysel korumayı hedeflemiştir. Ancak çalışma ortamında çalışanların KKD’ları kullanmaması durumunda ortaya birtakım risklerin çıkabileceğini doğurmuştur. Bununla ilgili olarak da bu çalışmada bir risk değerlendirilmesi yapılmıştır. Buradan yola çıkarak tehlikelerin belirlenmesi için çalışma ortamı ziyaret edilmiş, ortamdaki tehlikeli durumlar ve riskler belirlenmiştir. Tehlike ve risk durumları belirlenirken sadece ortam ziyareti değil aynı zamanda yeraltı çalışanlarından da (mühendis ve işçi) yardım alınmıştır.

Risk değerlendirmesi analizinde Risk değerlendirme matrisi (L-Tipi) metodu kullanılmıştır. Risk matrisi değerlendirmesinde, riskin olma olasılığı ve olduktan sonra yaratacağı etki gibi iki değişken analiz edilir. Belirlenen risklerin her birine bir olasılık değeri (düşük intimalden yüksek ihtimale kadar) ve ayrıca riskin sonunda yaratacağı etkiye de bir şiddet değeri (çok hafiften çok ciddiye kadar) verilir. Şiddet ve olasılık düzeyleri için en düşük 1 , en yüksek 5 değeri kullanılır (Çizelge 1). Burada risk değerlendirmesi şiddet ve olasılık düzeylerinin çarpılması sonucu elde edilen risk skoru (veya puanı) ile analiz edilir (Eşitlik 1).

$\mathrm{R}=$ Olasılık $X$ Şiddet

Belirlenen skorlar için Çizelge 2'deki risk değerlendirme tablosu kullanılarak bir analiz ve değerlendirme yapılır. 
Değerlendirme sırasında risk skoru 2-6 arasında ise "düşük", 8-15 arasında ise "orta" ve 16-25 arasında ise "yüksek" risk durumu olduğu anlamına gelmektedir (Çizelge 3).

Çizelge 1. Risk değerlendirmesi için Olasılık ve Şiddet tanımlamaları.

Table 1. Probability and severity definitions for risk assessment.

\begin{tabular}{llllll}
\hline Olasılık & 1-Yılda bir & 2-Üç ayda bir & 3-Ayda bir & 4-Haftada bir & 5-Sürekli (vardiyada) \\
\hline Şiddet & 1- Hafif & 2-İlkyardımlı & 3-İstirahatli & 4-Üç günden çok & 5- İş görmez/Ölümlü \\
\hline
\end{tabular}

Çizelge 2. Risk matrisi değerlendirme çizelgesi.

Table 2. Risk matrix assessment chart.

\begin{tabular}{|c|c|c|c|c|c|c|}
\hline \multicolumn{7}{|c|}{ Risk Analizi Matriksi (R) } \\
\hline \multirow{2}{*}{\multicolumn{2}{|c|}{ 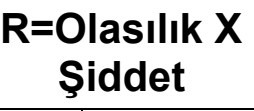 }} & \multicolumn{5}{|c|}{ Şiddet } \\
\hline & & 1 & 2 & 3 & 4 & 5 \\
\hline \multirow{5}{*}{$\begin{array}{l}\frac{y}{\overline{\bar{n}}} \\
\frac{\bar{D}}{\bar{O}}\end{array}$} & 1 & 1 & 2 & 3 & 4 & 5 \\
\hline & 2 & 2 & 4 & 6 & 8 & 10 \\
\hline & 3 & 3 & 6 & 9 & 12 & 15 \\
\hline & 4 & 4 & 8 & 12 & 16 & 20 \\
\hline & 5 & 5 & 10 & 15 & 20 & 25 \\
\hline
\end{tabular}

Çizelge 3. Risk değeri aksiyon ve zamanlama çizelgesi.

Table 3. Risk value action and timing chart.

\begin{tabular}{lll}
\hline \multicolumn{2}{c}{ Risk Değeri } & \multicolumn{1}{c}{ Aksiyon ve Zaman Planlaması } \\
\hline $\mathbf{2 - 6}$ & $\begin{array}{l}\text { Kabul } \\
\text { Edilebilir } \\
\text { Risk }\end{array}$ & $\begin{array}{l}\text { Riski bu seviyede tutmak için mevcut } \\
\text { kontroller sürekli takip edilmelidir. }\end{array}$ \\
\hline $\mathbf{8 - 1 5}$ & $\begin{array}{l}\text { Dikkate } \\
\text { Değer } \\
\text { Risk }\end{array}$ & $\begin{array}{l}\text { Bu Risklere Mümkün Olduğu Kadar çabuk } \\
\text { Müdahale Edilmelidir. (Birkaç Ay İçerisinde) }\end{array}$ \\
\hline $\mathbf{1 6 - 2 5}$ & $\begin{array}{l}\text { Kabul } \\
\text { Edilemez } \\
\text { Risk }\end{array}$ & $\begin{array}{l}\text { Hemen Gerekli Önlemler Alınmalıdır. En } \\
\text { azı̈ndan Dikkate Değer Risk (8-15 puan) } \\
\text { işe devam edilmemelidir. }\end{array}$ \\
\hline
\end{tabular}




\section{BULGULAR VE TARTIŞMA}

\section{Kullanılan KKD'ler}

Genel olarak bu tip madenlerde ve araştırmaya konu olan madende kullanılan KKD'lar aşağıdaki gibidir;

- CO maskesi

- Baret

- Toz Maskesi

- Tepe lambası

- İş gözlüğü

- İş ayakkabısı

- Tulum

- Kulak tıkacı şeklindedir.

Çalışmada, yeraltı altın madeninde bazı spesifik işlerde çalışan kişilerin kullandığı özel KKD dikkate alınmamıştır. Çalışmada yeraltında tüm çalışanlar tarafından yaygın biçimde kullanılan KKD hedef seçilmiştir.

\section{Belirlenen Tehlikeler}

Çalışmada Altın madeninde yeraltı çalışanlarının kullandığı Baret, İş gözlüğü, İş ayakkabısı, CO maskesi, Tepe lambası, Tulum, Toz Maskesi gibi KKD’lar üzerine Tehlike ve Riskler belirlenmiştir. Bunları belirlemek için yeraltı çalışma ortamı ziyaret edilerek çalışma esnasında oluşabilecek tehlike ve riskler üzerine tespitler yapılmış ve ayrıca yeraltı çalışanlarından bu konuda yardım alınmıştır. Yapılan tespitler sonucu belirlenen Tehlike ve Risk durumları Çizelge 4'te verilmiştir.

Çalışma ortamındaki tehlike durumları ana galeri, yan galerileri, üretim alanı ve yeni açılan galeriler olmak üzere farklı alanlarda belirlenmiştir. Ayrıca galerilerde makine ekipman içerisinde çalışma ortamı da tehlike ve risklerin belirlenmesine kaynak olmuştur. Buralarda olası tehlikeler ve sonrasında oluşması muhtemel riskler iş sağlığı ve güvenliği biriminin daha önceki kayıtlarında da faydalanılarak belirlenmiştir. Kullanılan KKD'lara göre çalışanlar üzerinde oluşması muhtemel risk durumları ortaya çıkartılmıştır. En büyük risk durumu iş görmezlik/ölümlü şeklinde olurken, en düşük risk ise yaralanma şeklinde ifade edilmiştir. 
Çizelge 4. Altın madeninde yeraltında kullanılan KKD'lar ve kullanılmama durumunda oluşacak muhtemel tehlike ve risk durumları.

Table 4. PPE used underground in the gold mine and possible danger and risk situations in case of non-use.

\begin{tabular}{|c|c|c|}
\hline KKD Kaynağı & Tehlike & Risk \\
\hline CO Maskesi & $\begin{array}{l}\text { - Yeraltı gazlarına maruz kalınması. } \\
\text { - Maskenin yeraltında kullanılmaması. } \\
\text { - CO maskesinin deforme olması ve } \\
\text { basıncının düşmesi. }\end{array}$ & $\begin{array}{l}\text { • Zehirlenme. } \\
\text { • İş görmez/Ölümlü. }\end{array}$ \\
\hline Baret & $\begin{array}{l}\text { - Galeride göçük durumu veya kaya vb. } \\
\text { parçalar düşmesi. } \\
\text { - Düşme veya çarpma sonucu başına } \\
\text { ağır darbe alma. }\end{array}$ & $\begin{array}{l}\text { - Yaralanma. } \\
\text { - Ağır yaralanma. } \\
\text { - İş görmez/Ölümlü. }\end{array}$ \\
\hline Toz Maskesi & - Tozlu ortamda bulunma. & $\begin{array}{l}\text { - Tozlardan kaynaklı meslek } \\
\text { hastalıkları. }\end{array}$ \\
\hline Tepe Lambası & $\begin{array}{l}\text { - Yeraltına girerken tepe lambasının } \\
\text { kontrollerinin yapılmaması. }\end{array}$ & $\begin{array}{l}\text { - Araç çarpması. } \\
\text { - Yaralanma. } \\
\text { - Ağır yaralanma. } \\
\text { - İş görmez/Ölümlü. }\end{array}$ \\
\hline İş Gözlüğü & $\begin{array}{l}\text { - Çalışma esnasında ortaya çıkan } \\
\text { parçacıkların ve ortamdaki tozun göze } \\
\text { kaçması. } \\
\text { - İşe uygun gözlüklerin kullanılmaması. }\end{array}$ & $\begin{array}{l}\text { - Parça Batması. } \\
\text { - Geçici ya da sürekli görme } \\
\text { kaybı. }\end{array}$ \\
\hline İş Ayakkabısı & $\begin{array}{l}\text { - Ayağa sert malzemenin düşmesi veya } \\
\text { çivi vb. malzemelerin batması. } \\
\text { - Giyilen çizmenin su geçirmesi. } \\
\text { - Ayakkabıdan kaynakı mantar } \\
\text { oluşması. } \\
\text { - Uygun iş ayakkabısının giyilmemesi. }\end{array}$ & $\begin{array}{l}\text { - Ezilme, yaralanma. } \\
\text { - Enfeksiyon, kırık, çıkık. } \\
\text { - Uzuv kaybı. }\end{array}$ \\
\hline Tulum & $\begin{array}{l}\text { - Personelin yeraltına girerken } \\
\text { çalışacağı bölgeye uygun tulumu } \\
\text { giymemesi (görünürlüğe sahip vb.). }\end{array}$ & $\begin{array}{l}\text { - Yeraltında fark edilmeme, } \\
\text { - Vücuda makine ekipman, } \\
\text { kayaç vb. madde teması } \\
\text { sonucu yaralanma. } \\
\text { - Toz ve çeşitli kimyasalların } \\
\text { cilde teması. }\end{array}$ \\
\hline Kulak Tıkacı & - Çalışılan ortamın gürültülü olması. & $\begin{array}{l}\text { - Kulak çınlaması, } \\
\text { - İşitme kaybı (uzun süre } \\
\text { maruziyet) }\end{array}$ \\
\hline
\end{tabular}

\section{Risk Derecelendirme}

Risk değerlendirmesi yapabilmek için riskin meydana gelme olasılığı ve oluşması muhtemel şiddeti ile ilgili tanımlamalar yapmak gerekir. Yeraltı madeninde çalışanların KKD’ları kullanmadıklarında risklerin meydana gelme ihtimali ve olası şiddeti tanımlamaları Çizelge 1'den yararlanılarak yapılmıştır. Risklerin olasılık değerleri 1'den 5'e kadar olacak biçimde sırasıyla yılda bir, üç ayda bir, ayda bir, haftada bir ve sürekli (vardiyada) olarak belirlenmiştir. Şiddetleri ise benzer şekilde 1'den 5'e kadar olacak biçimde sırasıyla hafif, ilk yardımlı, istirahatli, üç günden çok ve iş görmezlik/ölümlü olarak belirlenmiştir. 


\section{Risk Analizi ve Değerlendirme}

Olasılık ve şiddet tanımlamalarından sonra bu çalışmada materyal olarak kullanılan KKD kaynakları için risk skoru belirlenmiştir (Çizelge 5). Risk skoru belirlerken mevcut yeraltı koşulları ve yeraltında çalışanların daha önceki gözlem ve deneyimlerden faydalanılmıştır. Yeraltında kullanılan KKD'lar için yapılan risk analizinde en yüksek risk skoru 25 ile CO Maskesine ait çıkmıştır. Toz Maskesi ve Baret için ise 20 risk skoru belirlenmiş ve CO Maskesinden sonra en yüksek risk skoruna sahip KKD’lardır. Tulum, İş ayakkabısı ve İş Gözlüğü ise 12 risk skoru ile orta seviyede risk skoruna, Kulak tıkacı ise 6 risk skoru ile en düşük skora sahiptir (Şekil 1).

Çizelge 5. KKD’lar için belirlenen risk skoru ve şiddet derecesi.

Table 5. Risk score and severity rating for PPE.

\begin{tabular}{lccccc}
\hline KKD Kaynağı & Olasılık & Şiddet & Risk Skoru & Öncelik Sırası & Şiddet Derecesi \\
\hline CO Maskesi & 5 & 5 & 25 & 1 & Yüksek \\
\hline Baret & 4 & 5 & 20 & 1 & Yüksek \\
\hline Toz Maskesi & 4 & 5 & 20 & 1 & Yüksek \\
\hline Tepe Lambası & 3 & 5 & 15 & 2 & Orta \\
\hline İş Gözlüğü & 3 & 4 & 12 & 2 & Orta \\
\hline İş Ayakkabısı & 4 & 3 & 12 & 2 & Orta \\
\hline Tulum & 3 & 4 & 12 & 2 & Orta \\
\hline Kulak Tıkacı & 2 & 3 & 6 & 3 & Düşük \\
\hline
\end{tabular}

KKD’ların yeraltı maden işletmelerinde çalışanların kullanmama durumlarıyla ilgili yapılan risk analizi sonucu hemen hemen tüm materyaller için risk değerleri Kabul Edilemez Risk ve Dikkate Değer olarak çıkmıştır. Bu risk değerleri orta ve yüksek şiddet derecesine sahip olup mümkün olduğunca erken müdahale gerektiren ve hatta bir önceki risk derecesine indirilmeden bu risk derecelerinde işe devam edilmemesi gerektiren durumlardır.

\section{Alınması Gereken Önlemler}

Tehlike durumları belirlenen ve risk dereceleri kabul edilemez ve Dikkate Değer çıkan KKD’lar ile ilgili bazı düzeltici ve önleyici faaliyetler yapılması gerekliliği ortaya çıkmaktadır. $\mathrm{Bu}$ faaliyetler kapsamında alınması gereken önlemlerin (kontrol tedbirleri) planlaması yapılır ve uygulamaya konur. Bu çerçevede alınması gereken önlemler Çizelge 6'da verilmiştir. 


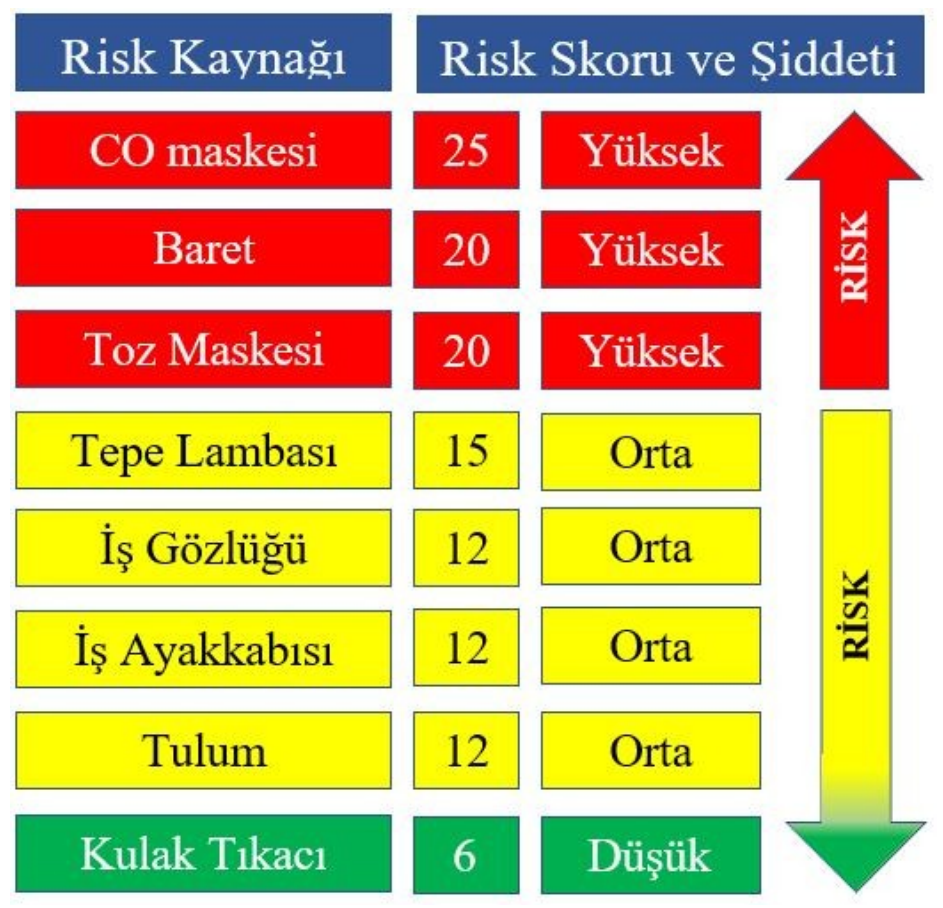

Şekil 1. Yeraltı altın madeni işletmesinde kullanılan KKD'ların risk dereceleri.

Figure 1. Risk grades of PPE used in underground gold mine.

Özellikle çok tehlikeli ve tehlikeli çalışma koşullarında işletmelerin iş sağlığı ve güvenliği ile ilgili politikalarının başında toplu korumaya öncelik verilmesi gelmektedir. Ancak toplu koruma tedbirlerinin yapılamadığı durumlarında KKD'ların kullanılması gerekmekte ve iş sağlığı ve güvenliği mevzuatlarında da bu durum ifade edilmektedir (Resmi Gazete, 2012). Özellikle, yeraltı maden işletmeleri gibi çalışma ortamlarının çok tehlikeli olduğu durumlarda toplu koruma tedbirlerinin yanında KKD'ların kullanılmasının da zorunlu olduğu bir gerçektir. Yapılan risk analizi sonucu KKD'lara işveren ve çalışanların önem vermesi gerektiği ortaya çıkmaktadır. Ayrıca, yeraltı maden işletmesinde çalışanların kaza ve/veya meslek hastalıklarına yakalanmalarının önüne geçilmesi için bu çalışmada ortaya konan tehlike ve risklere karşı alınması gereken önlemlerin uygulanmasının, sürekli izlenmesinin ve eğitimlerde bahsedilmesinin gerekliliği de ortaya çıkmıştır.

Demirbilek ve Çakır (2008) yaptıkları çalışmalarında KKD'ın uygun kullanımı açısından çalışanların eğitiminin gerekliliğine vurgu yapmıştır. Yapılması gerekli olan bu eğitimlerde KKD'ın ne zaman gerekli olduğu, hangi türüne intiyaç duyulduğu, uygun kullanımı, sınırııkları ve bakımının nasıl uygun şekilde yapılması gerektiği konularına değinilmesi gerektiğini belirtmişlerdir. Ancak yapılan bu çalışma göstermektedir ki, eğitimlerde bahsedilen bu konuların dışında KKD yönelik yapılan risk analizleri sonucu ortaya çıkan tehlike ve risklerin ve alınması gereken önlemlerin öneminin de eğitimin konularının bir parçası olması gerektiğidir. 
Çizelge 6. Alınacak önlemler (Kontrol tedbirleri)

Table 6. Measures to be taken (Control measures).

\begin{tabular}{|c|c|}
\hline KKD Kaynağı & Alınacak Önlemler (Kontrol Tedbirleri) \\
\hline CO Maskesi & $\begin{array}{l}\text { - CO maskesi yeraltına giren tüm personelin acil bir durumda kolay } \\
\text { - Şekilde kullanabileceği şekilde olmalı. } \\
\text { - CO maskesini takmadan önce kullanılabilir olup olmadığını kontrol } \\
\text { ederek üzerine almalıdır. } \\
\text { - Deforme olan ya da kullanım süresi bitmiş maskeler kullanılmamalı } \\
\text { maskelerin nasıl kullanılması ile ilgili hem teorik hem de uygulamalı } \\
\text { eğitimlerin verilmesi. } \\
\text { - OFK maskesini yanına almadan yapılması gereken kontroller; OFK } \\
\text { maskesinin mührünün üzerinde olması, darbe almamış olması, } \\
\text { nemli olmaması, sabitlemek için deforme olmamış bel kayışı. }\end{array}$ \\
\hline Baret & $\begin{array}{l}\text { - Yeraltında baret kullanması zorunlu olmalı. } \\
\text { - Baretin nesne çarpmalarına karşı dirençli. } \\
\text { - Baret içi süspansiyonu olmalı ve çarpma şiddetini emmeli. } \\
\text { - Suya dayanaklı ve yanmaya karşı dirençli. } \\
\text { - Kolayca kafaya oturacak şekilde ayarlanabilir olmalı. }\end{array}$ \\
\hline Toz Maskesi & $\begin{array}{l}\text { - Toz maskelerinin alana uygun olarak ffp1, ffp2, ffp3 maskelerinin } \\
\text { kullanım alanlarının belirlenmesi. } \\
\text { - Çalışanlara bununla ilgili eğitimlerin verilerek uygulamalı olarak } \\
\text { taktırılması ve yüze oturması sağlanmalıdır. } \\
\text { - Maskeden kaynaklı buharlaşmayı önlemek için burun üzerinde } \\
\text { bulunan demir aparatın burun üzerine tam oturtulması. }\end{array}$ \\
\hline Tepe Lambası & $\begin{array}{l}\text { - Tepe lambasının çalıştığından emin olduktan sonra yanına almalı. } \\
\text { - Yeraltında nasıl kullanılması gerektiği ile ilgili bilgilere sahip } \\
\text { olmalıdır. }\end{array}$ \\
\hline İş Gözlüğü & $\begin{array}{l}\text { - Ortamda gözler için zararlı gaz ve taş sıçrama ihtimali bulunması } \\
\text { halinde çerçeve gövdesi gözleri sıkıca çevreleyen göz koruyucular } \\
\text { kullanılmalıdır. } \\
\text { - Koruyucu gözlükler EN } 166 \text { standardına uygun olarak üretilmiş } \\
\text { olmalıdır. } \\
\text { - Göz koruyucuların kullanım alanları ve performans değerleri ürün } \\
\text { üzerinde sembol ve işaretlemeler ile ifade edilmektedir. Tespit } \\
\text { edilen riskler dahilinde bu semboller kontrol edilerek seçim } \\
\text { yapılmalıdır. }\end{array}$ \\
\hline İş Ayakkabısı & $\begin{array}{l}\text { - Madenin kuru ya da ıslak olmasına bağlı olarak, deri ya da lastik iş̧ } \\
\text { - Ayakkabıları kullanılabilir. } \\
\text { - Ayakkabılarda delinme ve kırılmaya dayanıklı, kaymayı önleyici bir } \\
\text { taban, darbeye karşı dayanıklı bir dış yüzey ve parça düşmelerine } \\
\text { karşı burunda çelik maskarat bulunmalıdır. } \\
\text { - Çalş̧ma esnasında ayağa gelebilecek darbe, çarpma ve malzeme } \\
\text { düşmesine karşı koruyucu özelliği olan iş ayakkabısı, bot veya } \\
\text { çizme giyilmelidir. } \\
\text { - Oluşabilecek mantar vb. ayak hastalıklarına karşı koruyucu } \\
\text { ayakkabılar çorapsız ve ıslak ayak ile giyilmemelidir. } \\
\text { - Madencilik sektöründe çalışan ve sahaya dahil olan kişilerin tümü } \\
\text { koruyucu ayakkabı giymelidir. }\end{array}$ \\
\hline Tulum & $\begin{array}{l}\text { - Yeraltına girmeden önce giyilecek tulumun çalışılan alana uygun } \\
\text { olup olmadığı kontrol edilmeli. } \\
\text { - Üzerinde fark edilmeyi sağlayan fosfor kısmı olmalı. } \\
\text { - Tek kullanımlıksa kullanıldıktan sonra uygun atık kutularına } \\
\text { bırakılmalıdır. }\end{array}$ \\
\hline Kulak Tıkacı & $\begin{array}{l}\text { - Kulağa zarar verecek sertlikte olmamalı. } \\
\text { - Ortamda bulunan ses şiddetini makul seviye indirecek kalitede } \\
\text { olmalı. }\end{array}$ \\
\hline
\end{tabular}




\section{SONUÇLAR}

Madencilik gibi çok tehlikeli iş kolu sınıfında bulunan iş yerlerinde mutlaka faaliyetler öncesinde sağlıklı ve güvenli çalışma ortamlarının oluşturulması için risk analizleri yaparak tüm risklerin belirlenmesi ve bu risklere karşı gerekli tedbirlerin alınarak toplu korumanın sağlanması gerekmektedir. Toplu korumanın yapılamadığı durumlarda ise uygun KKD kullanımının yapılarak bireysel korumanın gerçekleştirilmesi gerekmektedir.

Ancak madencilik gibi benzer çok tehlikeli iş kollarında KKD kullanımının yapılmadığı durumlarda risk ve tehlikenin boyutu artmaktadır. Bu çalışmada özellikle yeraltı madenlerinde bazı KKD’ların kullanılmamasının çok çeşitli tehlike ve risklere neden olduğu yapılan Risk değerlendirme matrisi (L-Tipi) yöntemiyle belirlenmiştir. Yapılan analiz yöntemi sonrasında en yüksek risk skorlarının CO maskesi, Baret ve Toz Maskesinde olduğu belirlenmiştir. Tepe Lambası, İş Gözlüğü, İş Ayakkabısı ve Tulum ise orta düzey risk grubunda yer almış, kulak tıkacı ise düşük risk derecesine sahiptir. Sonuç olarak, yapılan risk analizi ile hemen hemen tüm materyaller için risk değerleri Kabul Edilemez Risk ve Dikkate Değer seviyede çıkmıştır. Bu durumda özellikle yeraltı maden işletmelerinde işverenler ve çalışanların KKD temini ve kullanımına yönelik sorumlulukları artmaktadır. İş verenlerin çalışma ortamına uygun KKD’ların belirlemesi ve sağlaması, çalışanlara KKD eğitimi vermesi gerekmektedir. Ayrıca KKD eğitim içeriklerinde sadece hangi türü, uygun kullanımları ve ne zaman kullanıldıklarına yönelik değil, KKD'ın kullanılmadığında ortaya çıkabilecek olası tehlike ve risklerin boyutu ve alınması gereken önlemlerin öneminin de anlatılması ve bu konudaki eğitimleri arttırması gerekmektedir.

\section{KAYNAKLAR}

Akpınar, T., 2015. İş Sağlığı ve İş Güvenliği İşçi İşveren Rehberi. İstanbul On İki Levha Yayıncılık, İstanbul.

Cervatoğlu, E., 2003. İş Sağlığı ve Güvenliği Konusunda Bir Değerlendirme. Türk Tabipler Birliği Mesleki Sağlık ve Güvenlik Dergisi, 13, 23-29.

Çolak, M., Aygürler, C., Çetin, T., 2018. Madencilik Sektöründe İş Sağlığı ve Güvenliği Açısından Risk Analizi, 4th Global Business Research Congress (GBRC -2018), Vol.7, pp.285-289.

ÇSGB, 2016. Maden Sektörü Kişisel Koruyucu Donanım Rehberi, İş Sağlığı ve Güvenliği Genel Müdürlüğü Piyasa Gözetimi ve Denetimi Daire Başkanlığı, Ankara, sayfa;1-32. 
Demirbilek, T., Çakır, Ö., 2008. Kişisel Koruyucu Donanım Kullanımını Etkileyen Bireysel ve Örgütsel Değişkenler, Dokuz Eylül Üniversitesi İktisadi ve İdari Bilimler Fakültesi Dergisi, 23, 2, 173-191.

Ernst \& Young, 2012. Dünyada ve Türkiye'de Madencilik Sektörü. https://madencilikrehberi.files.wordpress.com/2012/04/madencilik-sektc3b6rc3bc.pdf, 31 Temmuz 2019.

Eser, A., 2015. Maden İşlerinde Solunum Koruyucu Donanımlar, Maden İşletmelerinde İşçi Sağlığı ve İş Güvenliği Sempozyumu'2015, 21-22 Aralık, Adana, sayfa:301-311.

Hasanhanoğlu, C., 2020. Çalışanların Korunmasına Yönelik İşletme Öncelik ve İsg Politikaları Kapsamında Çalışanlarda Kişisel Koruyucu Donanım Kullanma Farkındalığı ve Bilinç Düzeyinin İncelenmesi-Çiftay A.Ş. İşletmesi Maden Sahası KKD Kullanım Etkinliği Çalışması, Journal of Advance Research in Business Management and Accounting, Volume-6, Issue-1, 1-23.

Kahya, E., Ulutaş, B., Özkan, N. F., 2019. Metal Endüstrisinde Kişisel Koruyucu Donanım Kullanımının Analizi. Selçuk Üniversitesi Mühendislik, Bilim ve Teknoloji Dergisi, 7 (2), 420-433.

Karaahmetoğlu, A., 2019. 6331 Sayılı İş Sağlığı ve Güvenliği Kanunu Bağlamında Soma Madenlerinin İş Sağlığı ve Güvenliği Açısından Değerlendirilmesi. Sosyal Siyaset Konferansları Dergisi, 76, 89-128.

Karadağ, K.Ö., 2000. Ankara ilinde üç taş ocağı ile iki kum ocağının ve çalışanlarının işçi sağlığı ve iş güvenliği açısından değerlendirilmesi. Hacettepe Üniversitesi Sağlık Bilimler Enstitüsü Bilim Uzmanlığı Tezi, Ankara.

Karvan, R., 2019. Risk Değerlendirme Metotları. https://docplayer.biz.tr, 31 Temmuz 2019. Kasap, Y., Subaşı E., 2011. Analitik hiyerarşi prosesi ile açık işletme madenciliğinde risk denetimi. Maden İşletmelerinde İşçi Sağlığı ve İş Güvenliği Sempozyumu Bildiriler Kitabı, Zonguldak.

Koçak, D., 2019. Bir Kömür Madeninde İş Sağlığı ve Güvenliği Risk Değerlendirmesi İçin Uygun Yöntem Seçimi. Yüksek Lisans Tezi, Hacettepe Üniversitesi Fen Bilimleri Enstitüsü, Ankara.

OSHA (Occupational Safety and Health Administration), 2004. Personal Protective Equipment. U.S. Department of Labor, Washington D.C., pp. 1-44.

Önder, S., Suner, N., Önder, M., 2011a. Madencilik Sektöründe Meydana Gelen İş Kazalarının Risk Değerlendirme Karar Matrisi ile İncelenmesi. Türkiye 22. Uluslararası Madencilik Kongresi ve Sergisi, Ankara, pp.399-406. 
Önder, S., Mutlu, M., Önder, M., 2011b. Açık İşletme Kömür Madenciliğindeki İş Kazalarının Risk Değerlendirme Karar Matrisi ile Değerlendirilmesi. Maden İşletmelerinde İşçi Sağlığı ve İş Güvenliği Sempozyumu'2011 Bildiriler Kitabı, 24-25 Kasım 2011, Zonguldak, sayfa:155-162.

Özkılıç, Ö., 2005. İş Sağlığı ve Güvenliği, Yönetim Sistemleri ve Risk Değerlendirme Metodolojileri. Türkiye İşveren Sendikaları Konfederasyonu, Ajans-Türk Matbaacılık, Ankara.

Resmi Gazete, 2012. İş Sağlığı ve Güvenliği Risk Değerlendirmesi Yönetmeliği. https://www.mevzuat.gov.tr/Metin.Aspx?MevzuatKod=7.5.16925\&Mevzuatlliski=0\&so urceXmlSearch, 29 Mart 2020.

Tozman, B., 2010. Türkiye Madencilik Sektöründe İ̧ Kazalarının İstatistiksel Analizi. Yüksek Lisans Tezi, Eskişehir Osmangazi Üniversitesi Fen Bilimleri Enstitüsü, Eskişehir. 